\title{
Premi Tahunan Asuransi Jiwa Dwiguna Pada Generali Insurance Group dengan Asumsi Seragam untuk Status Gabungan
}

\author{
Aprijon $^{1}$, Della Angriani ${ }^{2}$ \\ Jurusan Matematika, Fakultas Sains dan Teknologi, UIN Sultan Syarif Kasim Riau \\ Jl. HR. Soebrantas No. 155 Simpang Baru, Panam, Pekanbaru, 28293 \\ Email: aprijonanas@gmail.com,dellaanggriani20@gmail.com
}

\begin{abstract}
ABSTRAK
Penelitian ini dilakukan pada perusahaan Generali Insurance Group, terletak di Jl. Arifin Ahmad Pekanbaru. Penelitian ini menggunkan metode asumsi seragam untuk menghitung premi tahunan asuransi jiwa dwiguna untuk status hidup gabungan. Untuk menghitung besarnya premi tahunan perlu dihitungterlebih faktor diskon, anuitas hidup awal, premi tunggal dan premi tahunan. Premi dapat dibayarkan secara bulanan, kwartil dan tahunan. Berdasarkan penelitian diperoleh pada setiap kasus, bahwa besarnya premi tahunan asuransi jiwa dwiguna dengan menggunakan asumsi seragam lebih kecil dibandingkan dengan premi tahunan asuransi jiwa yang diperoleh dari perusahaan.
\end{abstract}

Katakunci:Asuransijiwa dwiguna, anuitas, premi, asumsi seragam.

\begin{abstract}
This research was conducted at a Generali Insurance Group company, located at Arifin Ahmad, Pekanbaru. This study uses a uniform assumption method to calculate the annual premium of dual life insurance for combined living status. To calculate the amount of the annual premium needs to be calculate in advance the discount factor, initial life annuity, single premium and annual premium. Premiums can be paid monthly, quarterly and annually. Based on research obtained in each case, that the amount of the annual premium of dual life insurance using uniform assumptions is smaller than of life insurance obtained from the company.
\end{abstract}

Keywords: Dualpurpose lifeinsurance, annuity, premiums, uniform assumptions.

\section{Pendahuluan}

Belakangan ini perkembangan asuransi di Indonesia bisa dibilang cukup baik, di mana saat ini bisa menemukan berbagai jenis asuransi dan juga manfaatnya yang tentu saja dapat disesuaikan dengan berbagai macam kebutuhan asuransi yang diperlukan. Hal ini akan membantu untuk bisa mendapatkan layanan asuransi yang paling tepat dan berguna maksimal di dalam kehidupan. Asuransi jiwa adalah sebuah layanan asuransi yang digunakan sebagai bentuk perlindungan terhadap timbulnya kerugian finansial atau hilangnya pendapatan seseorang atau keluarga akibat adanya kematian anggota keluarga (tertanggung) yang biasanya menjadi sumber nafkah bagi keluarga tersebut. Untuk mengantisipasi hal tersebut, maka akan sangat bijak bila sejak awal menggunakan asuransi jiwa.Asuransi dalam Undang-Undang No. 2 Th 1992 tentang usaha perasuransian adalah perjanjian antara dua pihak atau lebih, di mana pihak penanggung mengikatkan diri kepada tertanggung, dengan menerima premi asuransi, untuk memberikan penggantian kepada tertanggung karena kerugian, kerusakan atau kehilangan keuntungan yang diharapkan atau tanggung jawab hukum pihak ke tiga yang mungkin akan diderita tertanggung, yang timbul dari suatu peristiwa yang tidak pasti, atau memberikan suatu pembayaran yang didasarkan atas meninggal atau hidupnya seseorang yang dipertanggungkan [7].Ada beberapa macam premi asuransi jiwa, diantaranya adalah premi tunggal, premi tahunan, dan premi pecahan.Premi yang dapat dibayarkan sekaligus disebut dengan premi tunggal.Premi yang dapat dibayarkan secara berkala, misalkan setiap tahun, disebut premi tahunan.Sedangkan premi pecahan adalah premi yang dapat dibayar pada tiap semester, tiga bulan sekali, ataupun setiap bulan. 
Penelitian terkait dengan asuransi jiwa dwiguna juga telah dilakukan oleh Pinawati (2017) dengan judul "Premi Tahunan Asuransi Jiwa Dwiguna dengan Asumsi Seragam"[4].Pada penelitian tersebut menggunakan asuransi jiwa dwiguna.Premi tahunan yang menggunakan asumsi seragam telah diteliti sebelumnya oleh Andiraja (2015) dengan judul "Premi Tahunan Asuransi Jiwa Berjangka dengan Asumsi Seragam untuk Status gabungan”[1]. Pada penelitian tersebut asuransi yang digunakan adalah asuransi jiwa berjangka untuk status gabungan.Berdasarkan hal tersebut, penulis tertarik untuk melakukan penelitian dengan judul "Premi Tahunan Asuransi Jiwa Dwiguna dengan Asumsi Seragam untuk Status Gabungan”.

\section{Metode dan Bahan Penelitian}

1. Penulis membahas kasus mengenaiperhitungan premi tahunan asuransi jiwa dwiguna untuk status gabungan. Asuransi jiwa dwiguna adalah suatu jenis asuransi yang memberikan uang pertanggungan kepada pemegang polis, baik meninggal maupun bertahan hidup pada masa pertanggungan mapun berakhirnya masa pertanggngan [1].

2. Generali Insurance Group adalah sebuah perusahaan yang didirikan pada tahun 1831 di Trieste, Italia. Saat ini, Generali Group sudah menjadi salah satu perusahaan asuransi jiwa terbesar di Eropa dan sudah dipercaya sebagai penyedia jasa asuransi yang terkemuka. Generali berhasil menjadi pemain utama industri asuransi jiwa dan investasi di Indonesia dengan strategi bisnis yang terdefinisi secara jelas. Didukung oleh lebih dari 11.000 agen pemasaran dan kantor agen di seluruh penjuru Indonesia, termasuk Pekanbaru. Adapun di wilayah Pekanbaru, Asuransi Generali telah bekerja sama dengan tujuh provider rumah sakit untuk melayani pesertanya, sementara secara nasional peserta asuransi itu dapat dilayani di lebih dari 1.000 rumah sakit.

\section{Peluang Hidup dan Peluang Meninggal}

Nilai dari peluang hidup dan peluang meninggal dapat ditentukan denganmenggunakan data yang ada pada tabel mortalita. Tabel mortalita merupakan tabelyang disusun berdasarkan data dari sekelompok orang peserta asuransi dengan kondisiyang sama yang berisi riwayat kehidupan dari sekelompok orang tersebut.Peluang hidup seseorang yang berusia $x$ hingga $t$ tahun dapat dinotasikan dengan tpx.Sehingga untuk persamaan peluang hidup seseorang yang berusia $x$ hingga $t$ tahundapat dinyatakan dengan [3]:

$$
{ }_{t} p_{x}=1-{ }_{t} q_{x}
$$

dengan tqx merupakan peluang meninggal seseorang yang berusia $x$ hingga $t$ tahunadalah sebagai berikut:

$$
{ }_{t} q_{x}=1-{ }_{t} p_{x}
$$

Pada suatu instansi atau perusahaan tidak menutup kemungkinan mempekerjakan pegawai atau karyawan yang memiliki hubungan sebagai suami-istri, ibu-anak dan lain sebagainya. Adakalanya perusahaan asuransi mengadakan pengelompokkan untuk peserta yang berusia $m$ tahun , misalnya dikarenakan oleh status hubungan suami-istri. Pengelompokkan ini sering disebut dengan gabungan [1].

Peluang hidup gabungan untuk $m$ orang peserta asuransi jiwa yang berusia $x_{1}, x_{2}, x_{3}, \ldots, x_{m}$ tahun hingga $t$ tahun berikutnya dinyatakan dengan:

$$
\begin{aligned}
p_{x_{1} x_{2} x_{3}, \ldots, x_{m}} & =p_{x_{1}} p_{x_{2}} p_{x_{3}} \ldots p_{x_{m}} \\
& =\frac{l_{x_{1}+t}}{l_{x_{1}}} \frac{l_{x_{2}+t}}{l_{x_{2}}} \frac{l_{x_{3}+t}}{l_{x_{3}}} \ldots \frac{l_{x_{m}+t}}{l_{x_{m}}}
\end{aligned}
$$

Dan peluang meninggal gabungan untuk $m$ orang peserta asuransi jiwa yang berusia $x_{1}, x_{2}, x_{3}, \ldots, x_{m}$ tahun hingga $t$ tahun berikutnya dinyatakan dengan:

$$
\begin{gathered}
q_{x_{1} x_{2} x_{3}, \ldots, x_{m}}=1-p_{x_{1} x_{2} x_{3}, \ldots, x_{m}} \\
=1-p_{x_{1}} p_{x_{2}} p_{x_{3}} \ldots p_{x_{m}}
\end{gathered}
$$




\section{Asumsi Seragam}

Asumsi seragam adalah asumsi yang menyatakan bahwa peluang keluar (peluang meninggal) untuk peserta asuransi disetiap waktu itu sama. Peluang keluar dari seseorang yang berusia $x$ tahun sampai $t$ tahun berikutnya dengan interval $0 \leq t<1$ dinotasikan dengan ${ }_{t} q_{x}$ menggunakan asumsiseragam dinyatakan sebagai berikut:

$$
{ }_{t} q_{x}=t q_{x}
$$

Kemudian dengan mensubtitusikan Persamaan (5) kepersamaan (1), diperoleh peluang hidup dari seseorang yang berusia $x$ tahun hingga $t$ tahun berikutnya adalah:

$$
{ }_{t} p_{x}=1-t q_{x}
$$

Asumsi inilah yang digunakan dalam menentukan anuitas dan premi jiwa.

\section{Vaktor Diskon}

Menentukan premi tunggal asuransi jiwa dan menentukan anuitas hidup, konsepbunga juga sangat diperlukan. Tingkat bunga merupakan perbandingan antara bungayang diperoleh terhadap modal yang diinvestasikan, yang disimbolkan dengan $i$ danfaktor diskon yang dinotasikan dengan $v$.

$v=\frac{1}{1+i}$

\section{Anuitas Hidup Awal Berjangka}

Anuitas hidup awal berjangka pembayaran dimulai pada awal periode, maka pembayaran dilakukan setiap tahun hingga $(n-1)$ tahun dan akan terhenti apabila tertanggung meninggal dunia sebelum tahun ke- $(n-1)$. Diketahui ${ }_{t} p_{x}$ menyatakan peluang hidup peserta asuransi jiwa yang berusia $x$ tahun bertahan hidup hingga $t$ tahun, $n$ jangka waktu pertanggungan dan $v$ menyatakan faktor diskon. Nilai tunai anuitas hidup awal berjangka dinyatakan dengan:

$$
\ddot{a}_{x: \bar{n} \mid}=\sum_{t=0}^{n-1} v^{t}{ }_{t}{ }_{t} p_{x}=1+v p_{x}+v^{2} p_{x}+v^{3} p_{x}+\cdots+v^{n-1} p_{x}
$$

\section{Premi Tunggal dan Premi Tahunan Dwiguna}

Premi tunggal asuransi jiwa dwi guna untuk peserta asuransi yang berusia $x$ tahun, dengan jangka pertanggungan selama $n$ tahun dan uang pertanggungan dibayarkan pada akhir tahun polis dinotasikan dengan $A_{x: \bar{n} \mid}$. Misalkan $v$ merupakan factor diskon, ${ }_{n} p_{x}$ menyatakan peluang peserta asuransi dapat hidup hingga $n$ tahun kemudian, maka premi tunggal asuransi jiwa dwiguna murni dengan masa pertanggungan asuransi selama $n$ tahun dan uang pertanggungan sebesar 1 satuan pembayaran dinyatakan sebagai berikut[3]:

$$
A_{x: \overline{n \mid}}=v^{n} \quad{ }_{t} p_{x}
$$

Premi tahunan asuransi jiwa yaitu nilai tunai premi sama dengan nilai tunai santunan, sehingga untuk premi tahunan asuransi jiwa dwiguna untuk peserta asuransi yang berusia $x$ tahun dengan jangka waktu pertanggungan selama $n$ tahun dan pembayaran premi dilakukan sampai akhir [3] dinyatakan dengan:

$$
P_{x: \bar{n} \mid}=R \frac{A_{x: \bar{n} \mid}}{\ddot{a}_{x: \bar{n} \mid}}
$$

\section{Hasil dan Pembahasan}

\section{Anuitas Hidup Awal Berjangka dengan Asumsi Seragam untuk Status Gabungan}

Berdasarkan Persamaan (8) diketahui nilai anuitas hidup awal berjangka untuk $n$ peserta asuransi jiwa yang berusia $x$ tahun adalah: 


$$
\ddot{a}_{x: \bar{n} \mid}=\sum_{t=0}^{n-1} v^{t}{ }_{t} p_{x}
$$

Dengan mensubstitusikan persamaan (8) dengan Persamaan (6) asumsi seragam, maka nilai anuitas hidup awal berjangka untuk peserta asuransi jiwa yang berusia $x$ tahun, dinyatakan dengan : $\ddot{a}_{x: \bar{n} \mid}=\sum_{t=0}^{n-1} v^{t}{ }_{t} p_{x}$

$$
\ddot{a}_{x: \bar{n} \mid}=\sum_{t=0}^{n-1} v^{t}\left(1-t q_{x}\right)
$$

Sehingga dapat ditunjukkan nilai anuitas awal pada status hidup gabungan berdasarkan asumsi seragam dari orang berusia $m$ tahun, dinyatakan dengan:

$$
\ddot{a}_{x_{1} x_{2} x_{3}, \ldots, x_{m}: \overline{n \mid}}=\sum_{t=0}^{n-1} v^{t}\left(1-t q_{x_{1} x_{2} x_{3}, \ldots, x_{m}}\right)
$$

\section{Premi Tunggal dengan Asumsi Seragam untuk Status Gabungan}

Premi tunggal asuransi jiwa dwiguna untuk peserta asuransi yang berusia $x$ tahun, dengan jangka pertanggungan selama $n$ tahun dan uang pertanggungan dibayarkan pada akhir tahun polis dinotasikan dengan $A_{x: \bar{n} \mid}$, berdasarkan Persamaan (9) dinyatakan dengan :

$$
A_{x: \bar{n} \mid}=v^{n} \quad{ }_{n} p_{x}
$$

Dengan mensubstitusikan Persamaan (9) dengan Persamaan (6) asumsi seragam, maka nilai Premi tunggal asuransi jiwa dwiguna untuk peserta asuransi yang berusia $x$ tahun, dengan jangka pertanggungan selama $n$ tahun, dinyatakan dengan:

$$
\begin{aligned}
& A_{x: \bar{n} \mid}=v^{n}{ }_{n} p_{x} \\
& A_{x: \bar{n}}=v^{n}\left(1-t q_{x}\right)
\end{aligned}
$$

Sehingga dapat ditunjukkan nilai premi tunggal pada status hidup gabungan berdasarkan asumsi seragam dari orang berusia $m$ tahun, dinyatakan dengan:

$$
A_{x_{1} x_{2} x_{3}, \ldots, x_{m}: \overline{n \mid}}=v^{n}\left(1-t q_{x_{1} x_{2} x_{3}, \ldots, x_{m}}\right)
$$

\section{Premi Tahunan dengan Asumsi Seragam untuk Status Gabungan}

Premi tahunan asuransi jiwa dwiguna untuk status gabungan dengan uang pertanggungan sebesar $R$ dapat dihitung dengan menggunakan Persamaan (10). Dengan mensubstitusikan Persamaan (12) dan (14) ke Persamaan (10), diperoleh:

$$
\begin{aligned}
P_{x: \bar{n} \mid}=R & \frac{A_{x: \bar{n} \mid}}{\ddot{a}_{x: \bar{n} \mid}} \\
& P_{x_{1} x_{2} x_{3}, \ldots, x_{m}: \bar{n} \mid}=R \frac{v^{t}\left(1-t q_{x_{1} x_{2} x_{3}, \ldots, x_{m}}\right)}{\sum_{t=0}^{n-1} v^{t}\left(1-t q_{x_{1} x_{2} x_{3}, \ldots, x_{m}}\right)}
\end{aligned}
$$

\section{Kasus Penerapan}

Berikut akan diberikan contoh kasus penerapan dengan data yang diperoleh dari Asuransi Generali untuk menghitung premi tahunan asuransi jiwa dwiguna dengan 31 orang peserta asuransi jiwa yang terdiri dari sekelompok keluarga, pegawai kantor dan sekolompok mahasiswa dengan menggunakan asumsi seragam.

\section{Kasus 1}

Keluarga bapak Aris Syahputra mengikuti suatu program asuransi jiwa dwiguna untuk status hidup gabungan, dimana setiap peserta memiliki usia yang berbeda. Mereka mengikuti program asuransi jiwa dwiguna dengan waktu pertanggungan 5 tahun, uang pertanggungans ebesar Rp.25.000.000 dan tingkat bunga $10 \%$ untuk setiap periode. Dari data pada lampiran A maka besarnya premi tahunan peserta asuransi jiwa dwiguna untuk status hidup gabungan dengan asumsi seragam.

\section{Penyelesaian:}

Berdasarkan data dari kasus 1 dapat diketahui bahwa:

$$
R=\text { Rp. } 25.000 .000
$$

$$
\begin{aligned}
& n=5 \\
& i=0,1
\end{aligned}
$$


Tabel 1. Data Peserta Asuransi Jiwa Keluarga Aris Syahputra

\begin{tabular}{|c|c|c|c|c|}
\hline No & Tanggal Masuk & Nama Nasabah & JenisKelamin & UsiaMasuk \\
\hline 1 & $13 / 03 / 2016$ & Aris Syahputra & Laki-laki & 41 \\
\hline 2 & $13 / 03 / 2016$ & DarmiYanti & Perempuan & 36 \\
\hline 3 & $13 / 03 / 2016$ & Riduan Hotler & Laki-laki & 27 \\
\hline 4 & $13 / 03 / 2016$ & Yuliza & Perempuan & 25 \\
\hline 5 & $13 / 03 / 2016$ & Fajri Fadli & Laki-laki & 15 \\
\hline
\end{tabular}

Sumber: Generali Insurance Group

Sebelum menentukan premi tahunan, terlebih dahulu ditentukan factor diskon dengan tingkat bunga 10\% dengan menggunakan Persamaan (7) diperoleh:

$$
v=\frac{1}{1+0,1}=0,9090
$$

Untuk memudahkan dalam menghitung nilai anuitas awal dan premi tunggal, maka dapat dihitung terlebih dahulu peluang meninggal peserta asuransi jiwa setiap tahunnya berdasarkan data dari Tabel 1 dan Tabel Mortalita Indonesia (TMI) pada tahun 1999 pada buku buku Futami I, diperoleh: 1. Peluang meninggal Aris Syahputra untuk $0,1,2,3,4,5$ tahun berikutnya adalah:

$$
\begin{gathered}
{ }_{0} q_{41}=0 q_{41}=0 \\
{ }_{0} q_{41}=1 q_{41}=\left(\frac{l_{41}-l_{42}}{l_{41}}\right)=\left(1-\frac{l_{42}}{l_{41}}\right)=\left(1-\frac{94700}{94930}\right)=0,002422 \\
{ }_{2} q_{41}=2 q_{41}=0,004844 \\
{ }_{3} q_{41}=3 q_{41}=0,007266 \\
{ }_{4} q_{41}=4 q_{41}=0,009688 \\
5 q_{41}=q_{41}=0,01211
\end{gathered}
$$

2. Peluang meninggal Darmi Yanti untuk $0,1,2,3,4,5$ tahun berikutnya adalah:

$$
\begin{gathered}
{ }_{1} q_{36}=0 q_{36}=0 \\
q_{36}=1 q_{36}=\left(\frac{l_{36}-l_{37}}{l_{36}}\right)=\left(1-\frac{l_{37}}{l_{36}}\right)=\left(1-\frac{96794}{96915}\right)=0,001248 \\
{ }_{2} q_{36}=2 q_{36}=0,002496 \\
{ }_{3} q_{36}=3 q_{36}=0,003744 \\
{ }_{4} q_{36}=4 q_{36}=0,004992 \\
{ }_{5} q_{36}=5 q_{36}=0,00624
\end{gathered}
$$

3. Peluang meninggal Riduan Hotler untuk $0,1,2,3,4,5$ tahun berikutnya adalah:

$$
\begin{gathered}
{ }_{1} q_{27}=1 q_{27}=\left(\frac{l_{27}-l_{28}}{l_{27}}\right)=\left(1-\frac{l_{28}}{l_{27}}\right)=\left(1-\frac{97007}{97138}\right)=0,001348 \\
{ }_{2} q_{27}=2 q_{27}=0,002696 \\
{ }_{3} q_{27}=3 q_{27}=0,004044 \\
{ }_{4} q_{27}=4 q_{27}=0,005392 \\
{ }_{5} q_{27}=5 q_{27}=0,00674
\end{gathered}
$$

4. Peluang meninggal Yuliza untuk $0,1,2,3,4,5$ tahun berikutnya adalah:

$$
\begin{gathered}
0 q_{25}=0 q_{25}=0 \\
{ }_{1} q_{25}=1 q_{25}=\left(\frac{l_{25}-l_{26}}{l_{25}}\right)=\left(1-\frac{l_{26}}{l_{25}}\right)=\left(1-\frac{97968}{98066}\right)=0,00099 \\
{ }_{2} q_{25}=2 q_{25}=0,00198 \\
{ }_{3} q_{25}=3 q_{25}=0,00297 \\
{ }_{4} q_{25}=4 q_{25}=0,00396 \\
5 q_{25}=5 q_{25}=0,00495
\end{gathered}
$$

5. Peluang meninggal Fajri Fadli untuk $0,1,2,3,4,5$ tahun berikutnya adalah: 


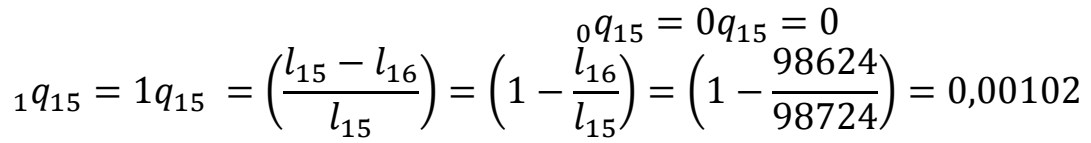

$$
\begin{aligned}
& { }_{2} q_{15}=2 q_{15}=0,00204 \\
& { }_{3} q_{15}=3 q_{15}=0,00306 \\
& { }_{4} q_{15}=4 q_{15}=0,00408 \\
& { }_{5} q_{15}=5 q_{15}=0,0051
\end{aligned}
$$

Berdasarkan peluang meninggal keluarga bapak Aris di atas dapat ditentukan premi tahunan untuk peserta asuransij iwa dwiguna untuk status hidup gabungan 5 orang peserta.Dengan menggunakan persamaan (12), diperoleh nilai anuitas hidup awal dwiguna untuk 5 orang peserta adalah:

$$
\begin{aligned}
\ddot{a}_{41,36,27,25,15: 5 \mid}= & \sum_{t=0}^{4} v^{t}\left(1-t q_{41,36,27,25,15}\right) \\
= & 0,9090(1-(0,0024220,0012480,001348 \ldots 0,00102)+ \\
& (0,9090)^{2}(0,0048440,0024960,002696 \ldots 0,00204)+ \\
& (0,9090)^{3}(0,0072660,0037440,004044 \ldots 0,00306)+ \\
& \left.(0,9090)^{4}(0,0096880,0049920,005392 \ldots 0,00408)\right) \\
= & 0,9090(0,99286)+0,826281(0,98602)+0,751089(0,979087)+ \\
& 0,682740(0,972191)=3,116464
\end{aligned}
$$

Kemudian, dengan menggunakan persamaan (14) diperoleh nilai premi tunggal asuransi jiwa dwiguna sebagai berikut:

$$
\begin{aligned}
& A_{41,36,27,25,15: 5 \mid}=v^{n}\left(1-t q_{41,36,27,25,15}\right) \\
& =(0,9090)^{5}(1-(0,002422 \quad 0,001248 \quad 0,001348 \ldots 0,00102) \\
& +(0,0048440,0024960,002696 \ldots 0,00204) \\
& +(0,0072660,0037440,004044 \ldots 0,00306 \\
& +(0,0096880,0049920,005392 \ldots 0,00408) \\
& +(0,012110,006240,00674 \ldots 0,0051)) \\
& =0,620610(0,931852) \\
& =0,57831666
\end{aligned}
$$

Jadi besarnya premi tunggal asuransi jiwa dwiguna dengan asumsi seragam status gabungan $n$ tahun dengan usia tertanggung Aris (41), Darmi (36), Riduan (27), Yuliza (25), Fajri (15) dan lama masa pertanggungan 5 tahun adalah 0,57831666. Apabila dikalikan dengan uang pertanggungan Rp. 25.000.000, maka besarnya premi tunggal yang harus dibayarkan sebesar Rp. 14.457.916,5.

Sehingga premi tahunannya adalah:

$$
\begin{gathered}
P_{41,36,27,25,15: 5 \mid}=R \frac{v^{n}\left(1-t q_{41,36,27,25,15}\right)}{\sum_{t=0}^{n-1} v^{t}\left(1-t q_{41,36,27,25,15}\right)} \\
=25.000 .000 \times \frac{0,57831666}{3,116464}=\text { Rp. } 4.639 .205
\end{gathered}
$$

Jadi, premi tahunan yang harus dibayarkan setiap tahunnya oleh keluarga Aris Syahputra adalah sebesar Rp. 4.639.205

Tabel 2. Hasil Rekapitulasi Kasus 1, Kasus 2 dan Kasus 3

\begin{tabular}{|c|c|c|c|c|}
\hline \multicolumn{2}{|c|}{ Nama Peserta Kasus 1,2,3 } & $\begin{array}{c}\text { Anuitas Hidup Awal } \\
\text { Berjangka }\end{array}$ & $\begin{array}{c}\text { Premi Tunggal } \times \\
(\mathbf{R})\end{array}$ & Premi Tahunan \\
\hline NO & Kasus 1 & & & \\
\hline 1 & Aris Syahputra & 3,116464 & Rp. 14.457.916 & Rp. 4.639 .205 \\
\hline 2 & Darmi Yanti & 3,116464 & Rp. 14.457.916 & Rp. 4.639 .205 \\
\hline 3 & Riduan Hotler & 3,116464 & Rp. 14.457 .916 & Rp. 4.639 .205 \\
\hline
\end{tabular}




\begin{tabular}{|c|c|c|c|c|}
\hline 4 & Yuliza & 3,116464 & Rp. 14.457.916 & Rp. 4.639.205 \\
\hline 5 & Fajri Fadli & 3,116464 & Rp. 14.457.916 & Rp. 4.639.205 \\
\hline NO & Kasus 2 & & & \\
\hline 1 & Fitra Dayanti & 3,062242 & Rp. 56.882 .412 & Rp. 18.626 .690 \\
\hline 2 & Arizan & 3,062242 & Rp. 56.882 .412 & Rp. 18.626 .690 \\
\hline 3 & Ida Rosita & 3,062242 & Rp. 56.882 .412 & Rp. 18.626 .690 \\
\hline 4 & David Ilham & 3,062242 & Rp. 56.882 .412 & Rp. 18.626 .690 \\
\hline 5 & Res Agustina & 3,062242 & Rp. 56.882 .412 & Rp. 18.626 .690 \\
\hline 6 & M. Ridwan & 3,062242 & Rp. 56.882 .412 & Rp. 18.626 .690 \\
\hline 7 & Dewi Nugraheni & 3,062242 & Rp. 56.882 .412 & Rp. 18.626 .690 \\
\hline 8 & Yendra Ardiman & 3,062242 & Rp. 56.882 .412 & Rp. 18.626 .690 \\
\hline 9 & Umi Salamah & 3,062242 & Rp. 56.882.412 & Rp. 18.626 .690 \\
\hline NO & Kasus 3 & & & \\
\hline 1 & Miladanis & 3,034223 & Rp. 14.004.998 & Rp. 4.615.676 \\
\hline 2 & Zulfitra & 3,034223 & Rp. 14.004 .998 & Rp. 4.615.676 \\
\hline 3 & Irawati & 3,034223 & Rp. 14.004.998 & Rp. 4.615.676 \\
\hline 4 & Muhammad Aria & 3,034223 & Rp. 14.004 .998 & Rp. 4.615.676 \\
\hline 5 & Reni Bafita & 3,034223 & Rp. 14.004.998 & Rp. 4.615.676 \\
\hline 6 & Mohammad Jefri & 3,034223 & Rp. 14.004.998 & Rp. 4.615.676 \\
\hline 7 & Raudatul Renti & 3,034223 & Rp. 14.004.998 & Rp. 4.615.676 \\
\hline 8 & Deny Syahputra & 3,034223 & Rp. 14.004.998 & Rp. 4.615.676 \\
\hline 9 & Kartika & 3,034223 & Rp. 14.004 .998 & Rp. 4.615.676 \\
\hline 10 & Renold & 3,034223 & Rp. 14.004.998 & Rp. 4.615.676 \\
\hline 11 & Afrina & 3,034223 & Rp. 14.004.998 & Rp. 4.615.676 \\
\hline 12 & Yuni Rahayu & 3,034223 & Rp. 14.004 .998 & Rp. 4.615.676 \\
\hline 13 & Efi Yanti & 3,034223 & Rp. 14.004.998 & Rp. 4.615.676 \\
\hline 14 & Dwi Andani & 3,034223 & Rp. 14.004.998 & Rp. 4.615.676 \\
\hline 15 & Siti Aisyah & 3,034223 & Rp. 14.004 .998 & Rp. 4.615.676 \\
\hline 16 & Wulandari & 3,034223 & Rp. 14.004.998 & Rp. 4.615.676 \\
\hline 17 & Ferdian Fikri & 3,034223 & Rp. 14.004.998 & Rp. 4.615.676 \\
\hline
\end{tabular}

Berdasarkan Tabel 2 di atas dapat dilihat bahwa anuitas awal hidup berjangka, premi tunggal dan premi tahunan untuk kasus 1, kasus 2 dan kasus 3 berbeda-beda. Jadi premi tahunan yang harus 
dibayarkan setiap tahunnya oleh masing-masing peserta berbeda-beda untuk kasus 1 sebesar Rp. 4.639.205, kasus 2 sebesar Rp. 18.626.690 dan kasus 3 sebesar Rp. 4.615.676.

\section{Kesimpulan}

Hasil pembahasan dari kasus 1, kasus 2 dan kasus 3, diketahui bahwa Besarnya premi tahunan asuransi jiwa dwiguna ditentukan oleh umur peserta asuransi, tingkat bunga, faktor diskon, nilai anuitas awal, premi tunggal dan uang pertanggungan. Uang pertanggungan berbeda-beda setiap kasus dalam jangka waktu 5 tahun dan bunga sebanyak 10\%. Kasus 1 premi tahunannya sebesar Rp. 4.639.205, kasus 2 premi tahunannya sebesar Rp. 18.626.690 dan kasus 3 premi tahunannya sebesar Rp. 4.615.676. Berdasarkan penelitian di perusahaan Generali Insurance Gruop premi tahunan asuransi jiwa dwiguna menggunakan asumsi seragam lebih kecil dari pada premi tahunan yang terdapat pada data asuransi perusahaan. Sehingga untuk pembayaran premi tahunan yang menggunakan asumsi seragam untuk status gabungan akan memberikan keuntungan bagi peserta asuransi jiwa.

\section{Daftar Pustaka}

[1] Andiraja, N., dan Desta, W., Premi Tahunan Asuransi Jiwa Berjangka dengan Asumsi Seragam untuk Status Gabungan, Jurnal Sains Matematika dan Statistika, Universitas islam Sultan Syarif Kasim Riau, 2015.

[2] Dickson, D.C.M., et al.,Actuarial Mathematics for Life Contingent Risks, Cambridge University Pers, Cambrige, 2009.

[3] Futami,T., Matematika Asuransi Jiwa Bagian 1,Terjemahan Gatot Herlianto, Penerbit Incorporated Foundation Oriental Life Insurance Cultural Development Center Japan, 1993.

[4] Pinawati, Siti., Premi Tahunan Asuransin Jiwa Dwiguna dengan Asumsi Seragam, Skripsi S1 Matematika Universitas Islam Negeri Sultan Syarif Kasim, Riau, 2017.

[5] Sembiring, dkk.,Matematika Keuangan, Bandung, M2S Bandung, 2005.

[6] Prakoso, D.,Hukum Asuransi Indonesia, PT RINEKA CIPTA, Jakarta, 2004.

[7] Mulhadi, M.,Dasar-Dasar Hukum Asuransi, PT Raja Grafindo Persada, Jakarta, 2017. 